\title{
Characterization of $\mathrm{Mo} / \mathrm{Mo}_{2} \mathrm{C}$ interface in MoSiBTiC alloy
}

\author{
Junya Nakamura $^{\mathrm{a}, *}$, Daiki Kanekon ${ }^{\mathrm{a}}$, Kyosuke Yoshimi ${ }^{\mathrm{a}}$ \\ ${ }^{a}$ Department of Materials Science and Engineering, Tohoku University, 6-6-02 Aramaki
}

Aza Aoba, Aoba-ku, Sendai 980-8579, Japan

*Corresponding author. Phone: +81(22)795-7326; Fax: +81(22)795-7325;

E-mail: nakamura@material.tohoku.ac.jp 
Abstract (100-200 words)

TiC-added Mo-Si-B alloys are stably composed of $\mathrm{Mo}_{\mathrm{ss}}, \mathrm{Mo}_{5} \mathrm{SiB}_{2},(\mathrm{Ti}, \mathrm{Mo}) \mathrm{C}$, and $(\mathrm{Mo}, \mathrm{Ti})_{2} \mathrm{C}$ phases. In the alloys, interfacial cracking mainly occurred at the interface between $\mathrm{Mo}_{\mathrm{ss}}$ and $\mathrm{Mo}_{5} \mathrm{SiB}_{2}\left(\mathrm{~T}_{2}\right)$. Thus, other interfaces such as between $\mathrm{Mo}_{\mathrm{ss}}$, $(\mathrm{Ti}, \mathrm{Mo}) \mathrm{C}$ and $(\mathrm{Mo}, \mathrm{Ti})_{2} \mathrm{C}$ were investigated for understanding the mechanical properties. The above three kinds of the interfaces have special atomistic structures probably favorable to the mechanical properties. At the interface of $\mathrm{Mo}_{\mathrm{ss}} /(\mathrm{Mo}, \mathrm{Ti})_{2} \mathrm{C},(\mathrm{Mo}, \mathrm{Ti})_{2} \mathrm{C}$ decomposes into $\mathrm{Mo}_{\mathrm{ss}}$ and (Ti,Mo)C, and then serrated, blade-shaped interfaces are formed. The $\mathrm{Mo}_{\mathrm{ss}} /(\mathrm{Ti}, \mathrm{Mo}) \mathrm{C}$ interface has an orientation relationship of $(110)_{\mathrm{Mo}} / /(111)_{(\mathrm{Ti}, \mathrm{Mo}) \mathrm{C}}$. The $(\mathrm{Ti}, \mathrm{Mo}) \mathrm{C} /(\mathrm{Mo}, \mathrm{Ti})_{2} \mathrm{C}$ interface forms a ledge and terrace semi-coherent structure, and its orientation relationship is $(111)_{(\mathrm{Ti}, \mathrm{Mo}) \mathrm{C}} / /(100)_{(\mathrm{Mo}, \mathrm{Ti})_{2} \mathrm{C}}$ and $[011]_{(\mathrm{Ti}, \mathrm{Mo}) \mathrm{C}} / /[010]_{(\mathrm{Mo}, \mathrm{Ti})_{2} \mathrm{C}}$. Therefore, $\mathrm{Mo}_{\mathrm{ss}},(\mathrm{Ti}, \mathrm{Mo}) \mathrm{C}$ and $(\mathrm{Mo}, \mathrm{Ti})_{2} \mathrm{C}$ have good coherency in the MoSiBTiC alloy. (119 words)

Keywords: Interfaces; Intermetallic alloys and compounds; Microstructure; borides; carbides; interface structure 


\section{Introduction}

Mo-Si-B-based alloys have good material performance as an ultrahigh

temperature material such as a high melting point and good high-temperature strength.

However, they also have some drawbacks such as a high density and low

room-temperature fracture toughness [1-7]. To overcome these disadvantages for

ultrahigh temperature applications, alloy design wit 4th and 5th element additions has

been investigated to improve the properties of Mo-Si-B alloys [8-13]. Quite recently,

we have challenged to develop new Mo-Si-B-based alloys with TiC addition [14-16].

The MoSiBTiC alloys have excellent properties such as a low density, superior

high-temperature strength $[14,15]$, and good room-temperature toughness [16]. For

understanding the mechanical properties, we should pay great attention to the interfaces

between Mo solid solution $\left(\mathrm{Mo}_{\mathrm{ss}}\right)$ and $(\mathrm{Ti}, \mathrm{Mo}) \mathrm{C}, \mathrm{Mo}_{\mathrm{ss}}$ and $(\mathrm{Mo}, \mathrm{Ti})_{2} \mathrm{C}$, and $(\mathrm{Ti}, \mathrm{Mo}) \mathrm{C}$

and $(\mathrm{Mo}, \mathrm{Ti})_{2} \mathrm{C}$ because interfacial cracking mainly occurred at the interface between

$\mathrm{Mo}_{\mathrm{ss}}$ and $\mathrm{Mo}_{5} \mathrm{SiB}_{2}\left(\mathrm{~T}_{2}\right)$. The above three kinds of the interfaces may have special

atomistic structures favorable to the mechanical properties. Therefore, the purpose of

this study is to observe and analyze the interfaces in the MoSiBTiC alloys by high-angle

annular-dark-field (HAADF) scanning transmission electron microscopy (STEM) and

high-resolution transmission electron microscopy (HRTEM). 


\section{Experimental procedure}

Samples were prepared with pure Mo (99.99 wt.\%), Si (99.9999 wt.\%), B

(99.95 wt.\%), and cold-pressed TiC powder (99 wt.\%; 2 to $5 \mu \mathrm{m}$ in diameter) using a conventional arc-melting technique in an Ar atmosphere. The nominal sample composition was Mo-5.0\%Si-10.0\%B-7.5\% Ti-7.5\% (at.\%). The cast ingots were then subjected to heat-treatment at $1800{ }^{\circ} \mathrm{C}$ for $24 \mathrm{~h}$ in an Ar atmosphere and subsequently furnace-cooled to room temperature. The temperature rapidly decreased to $1450{ }^{\circ} \mathrm{C}$ for $2 \mathrm{~min}$ and then reached room temperature for about $3 \mathrm{~h}$. X-ray diffractometry (XRD) using a Bruker AXS D8 Advance with $\mathrm{Cu}-\mathrm{K} \alpha$ radiation was carried out to identify constituent phases and measure lattice parameters. Microstructure observation and phase identification were performed using a scanning electron microscope (SEM; JEOL JSM-7800F). HAADF images were obtained using a field-emission-gun STEM (JEOL ARM200F) equipped with an energy dispersive X-ray spectroscope (EDS) operated at $200 \mathrm{keV}$.

\section{Results and discussion}

Figure 1 shows XRD spectrum of powder samples with the diameter of less 
than $46 \mu \mathrm{m}$. This medicates that the constituent phases, whose crystal structure and lattice parameter estimated from the spectrum are given in following brackets, were $\mathrm{Mo}_{\text {ss }}\left(\right.$ cubic, $\mathrm{a}=3.14 \AA$ ) $, \mathrm{Mo}_{5} \mathrm{SiB}_{2}\left(\mathrm{~T}_{2}\right.$; tetragonal, $\left.\mathrm{a}=6.01 \AA, \mathrm{c}=11.06 \AA\right),(\mathrm{Ti}, \mathrm{Mo}) \mathrm{C}$ (cubic, $\mathrm{a}=4.29 \AA$ ), and $(\mathrm{Mo}, \mathrm{Ti}){ }_{2} \mathrm{C}$ (orthorhombic, $\mathrm{a}=4.76 \AA, \mathrm{b}=6.10 \AA$, c $=5.22 \AA$ ).

Figure 2 shows back-scattered electron (BSE) images of the microstructures of the MoSiBTiC alloy after the heat treatment. An overview of the microstructure is shown in Figure 2a. Coarse $\mathrm{Mo}_{\mathrm{ss}}$ developed from the primary $\mathrm{Mo}_{\mathrm{ss}}$ phase through solidification and a fine $\mathrm{Mo}_{\mathrm{ss}}+\mathrm{T}_{2}+(\mathrm{Ti}, \mathrm{Mo}) \mathrm{C}+(\mathrm{Mo}, \mathrm{Ti})_{2} \mathrm{C}$ four-phase area developed from the four-phase peritecto-eutectic also through solidification were observed. Figure $2 \mathrm{~b}$ shows a high-magnification image of the four-phase area in the square marker in Figure 2a. In the image, $\mathrm{T}_{2}$ phase is shown by a grey contrast, while $(\mathrm{Mo}, \mathrm{Ti})_{2} \mathrm{C}$ is shown by a darker contrast. Furthermore, bright contrast indicates the $\mathrm{Mo}_{\mathrm{ss}}$ phase, and there are small (Ti,Mo)C dispersions (marked by white triangles) shown by black contrast. Figure 2c shows a part of a $\mathrm{Mo}_{\mathrm{ss}} /(\mathrm{Mo}, \mathrm{Ti})_{2} \mathrm{C}$ interface. Interestingly, the $\mathrm{Mo}_{\mathrm{ss}} /(\mathrm{Mo}, \mathrm{Ti})_{2} \mathrm{C}$ interface marked by white allows in Figure $2 b$ has a characteristic serrated shape.

Figure 3 shows STEM-BF images of a $\mathrm{Mo}_{\mathrm{ss}}, \mathrm{T}_{2}$ and $(\mathrm{Mo}, \mathrm{Ti})_{2} \mathrm{C}$ area. The serrated, blade-shaped interface was observed in parts of the $\mathrm{Mo}_{\mathrm{ss}}$ and $(\mathrm{Mo}, \mathrm{Ti})_{2} \mathrm{C}$ interface as shown in Figure 3b. Figure $3 c$ and d show the EDS Ti-K $\alpha$ and Mo-L $\alpha$ maps, 
respectively, obtained with STEM. The Mo map shows that Mo distributed in both the $\mathrm{Mo}_{\mathrm{ss}}$ and $(\mathrm{Mo}, \mathrm{Ti})_{2} \mathrm{C}$ phases. In the Ti map, it can be seen that Ti has a lower concentration on the $\mathrm{Mo}_{\mathrm{ss}}$ side and a higher concentration on the $(\mathrm{Mo}, \mathrm{Ti})_{2} \mathrm{C}$ side. Furthermore, along the $\mathrm{Mo}_{\mathrm{ss}} /(\mathrm{Mo}, \mathrm{Ti})_{2} \mathrm{C}$ interface, a high Ti-concentration phase was observed as shown by white triangles. The Mo concentration was low in the corresponding phase in the Mo map. From the analysis of obtained electron diffraction patterns, it was confirmed that a thin $(\mathrm{Ti}, \mathrm{Mo}) \mathrm{C}$ layer formed between $\mathrm{Mo}_{\mathrm{ss}}$ and $(\mathrm{Mo}, \mathrm{Ti})_{2} \mathrm{C}$ at the interface. The results of the EDS maps obtained in the present study were in accordance with the EDS analysis of each phase of the MoSiBTiC alloy reported previously [15].

Figure 4a shows a HAADF-STEM image of a part of a blade-shaped $\mathrm{Mo}_{\mathrm{ss}} /(\mathrm{Ti}, \mathrm{Mo}) \mathrm{C} /(\mathrm{Mo}, \mathrm{Ti})_{2} \mathrm{C}$ interfacial area. And figure $4 \mathrm{~b}$ shows $\mathrm{SAED}$ patterns of the blade-shaped $\mathrm{Mo}_{\mathrm{ss}} /(\mathrm{Ti}, \mathrm{Mo}) \mathrm{C} /(\mathrm{Mo}, \mathrm{Ti})_{2} \mathrm{C}$ interfacial area. The image was taken from $[0 \overline{1}$ $1]_{(\mathrm{Ti}, \mathrm{Mo}) \mathrm{C}} / /[010]_{(\mathrm{Mo}, \mathrm{Ti})_{2} \mathrm{C}} / /$ near-[11 1$]_{\mathrm{Mo}_{\mathrm{ss}}}$. The zone axis of $\mathrm{Mo}_{\mathrm{ss}}$ was slightly rotated from the $[1 \overline{1}]_{\mathrm{Mo}_{\mathrm{ss}}}$ direction around the $[110]_{\mathrm{Mo}_{\mathrm{ss}}}$ axis. The $\mathrm{Mo}_{\mathrm{ss}} /(\mathrm{Ti}, \mathrm{Mo}) \mathrm{C}$ interface shows an orientation relationship of $(110)_{\mathrm{Mo}_{\mathrm{Ss}}} / /(111)_{(\mathrm{Ti}, \mathrm{Mo}) \mathrm{C}}$. It is considered that the incident beam direction tilt is approximately $5.2^{\circ}$ away from the $[111]_{\mathrm{Mo}_{\mathrm{Ss}}}$ direction according to the orientation relationship and habit plane of $\mathrm{Mo} / \mathrm{MoC}, \mathrm{Mo} / \mathrm{TiC}$ reported in the literature 
[17-21]. The $\mathrm{Mo}_{\mathrm{ss}} /(\mathrm{Ti}, \mathrm{Mo}) \mathrm{C}$ interface was slightly tilted with respect to the observation direction, while the $(\mathrm{Ti}, \mathrm{Mo}) \mathrm{C} /(\mathrm{Mo}, \mathrm{Ti})_{2} \mathrm{C}$ interface was parallel to the observation direction. The $(\mathrm{Ti}, \mathrm{Mo}) \mathrm{C} /(\mathrm{Mo}, \mathrm{Ti})_{2} \mathrm{C}$ interface formed a ledge and terrace semi-coherent structure. The orientation relationship is given as;

$$
\begin{aligned}
& (111)_{(\mathrm{Ti}, \mathrm{Mo}) \mathrm{C}} / /(100)_{(\mathrm{Mo}, \mathrm{Ti})_{2} \mathrm{C}} \\
& {[0 \overline{1} 1]_{(\mathrm{Ti}, \mathrm{Mo}) \mathrm{C}} / /[010]_{(\mathrm{Mo}, \mathrm{Ti})_{2} \mathrm{C}}}
\end{aligned}
$$

These habit planes and orientation relationships are schematically shown in Figure 4c. Figure $4 \mathrm{~d}$ shows an enlarged image of the $(\mathrm{Ti}, \mathrm{Mo}) \mathrm{C} /(\mathrm{Mo}, \mathrm{Ti})_{2} \mathrm{C}$ interface area in the white square in Figure 4a, and Figure 4e shows a model of the atomic arrangement in the ledge area marked by the black rectangle in the direction along the white arrow in Figure $4 \mathrm{~d}$. The arrangement of Mo atoms in the $(\mathrm{Ti}, \mathrm{Mo}) \mathrm{C} /(\mathrm{Mo}, \mathrm{Ti})_{2} \mathrm{C}$ interface hardly changes between $(\mathrm{Ti}, \mathrm{Mo}) \mathrm{C}$ and $(\mathrm{Mo}, \mathrm{Ti})_{2} \mathrm{C}$, meaning that the interface is kept good coherency by the introduction of the ledges.

Figure 5a and $\mathrm{b}$ show the $\mathrm{Mo}_{\mathrm{ss}} /(\mathrm{Mo}, \mathrm{Ti})_{2} \mathrm{C}$ interface at the tip of a blade-shaped interface. The zone axis was parallel to $[111]_{\mathrm{Mo}_{\mathrm{ss}}}$. In the image, $(110)_{\mathrm{Mo}_{\mathrm{ss}}}$ planes appear to form a ledge. The habit plane of the $\mathrm{Mo} / \mathrm{Mo}_{2} \mathrm{C}$ (hexagonal) interface was reported to be $\{110\}_{\mathrm{Mo}} / /\{00 \cdot 1\}_{\mathrm{Mo}_{2} \mathrm{C}}[18]$. It was reported that the first-order transformation takes place in the $\mathrm{Mo}_{2} \mathrm{C}$ phase from the hexagonal $\varepsilon-\mathrm{Fe}_{2} \mathrm{~N}$-type superstructure to the 
orthorhombic $\zeta-\mathrm{Fe}_{2} \mathrm{~N}$-type superstructure in a mid-temperature range $\left(1100-1400{ }^{\circ} \mathrm{C}\right)$

$[22,23]$. These two kinds of structures correspond to the relations of $a \simeq c_{h c p}, b \simeq 2 a_{h c p}$, and $c \simeq \sqrt{3} a_{h c p}$. In this case, the elongated direction of the blades is parallel to this habit plane. Figures $5 \mathrm{c}$ to $\mathrm{f}$ show schematic diagrams of the formation mechanism of the serrated, blade-shaped interface. At first, the sympathetic nucleation $[24,25]$ of $\mathrm{Mo}_{\mathrm{ss}}$ in $(\mathrm{Mo}, \mathrm{Ti})_{2} \mathrm{C}$ appears at the $\mathrm{Mo}_{\mathrm{ss}} /(\mathrm{Mo}, \mathrm{Ti})_{2} \mathrm{C}$ interface (Figure $\left.5 \mathrm{~d}\right)$, and $(\mathrm{Ti}, \mathrm{Mo}) \mathrm{C}$ is successively precipitated at the newly created $\mathrm{Mo}_{\mathrm{ss}} /(\mathrm{Mo}, \mathrm{Ti})_{2} \mathrm{C}$ interface (Figure 5e). The $\mathrm{Mo}_{\mathrm{ss}} /(\mathrm{Ti}, \mathrm{Mo}) \mathrm{C}$ and $(\mathrm{Ti}, \mathrm{Mo}) \mathrm{C} /(\mathrm{Mo}, \mathrm{Ti})_{2} \mathrm{C}$ interfaces serve as habit planes during the growth of $\mathrm{Mo}_{\mathrm{ss}}$ in $(\mathrm{Mo}, \mathrm{Ti})_{2} \mathrm{C}$. Finally, the $\mathrm{Mo} /(\mathrm{Mo}, \mathrm{Ti})_{2} \mathrm{C}$ interface forms a blade-stacked structure as shown in Figure 5f. If these characteristic interfaces are able to be controlled, it may lead to further improvement of the mechanical properties of the MoSiBTiC alloys.

\section{Conclusions}

The atomic arrangement and orientation relationships of $\mathrm{Mo}_{\mathrm{ss}} /(\mathrm{Ti}, \mathrm{Mo}) \mathrm{C} /(\mathrm{Mo}, \mathrm{Ti})_{2} \mathrm{C}$ characteristic serrated shape interface has been studied by HAADF-STEM. The following conclusions were obtained:

(1) Thin (Ti,Mo)C layer formed in parts of the $\mathrm{Mo}_{\mathrm{ss}} /(\mathrm{Mo}, \mathrm{Ti})_{2} \mathrm{C}$ interface. Around the 
interface, $(\mathrm{Mo}, \mathrm{Ti})_{2} \mathrm{C}$ decomposes into $\mathrm{Mo}_{\mathrm{ss}}$ and $(\mathrm{Ti}, \mathrm{Mo}) \mathrm{C}$, and then serrated,

blade-shaped interfaces formed.

(2) The arrangement of Mo atoms in the $(\mathrm{Ti}, \mathrm{Mo}) \mathrm{C} /(\mathrm{Mo}, \mathrm{Ti})_{2} \mathrm{C}$ interface hardly changes between $(\mathrm{Ti}, \mathrm{Mo}) \mathrm{C}$ and $(\mathrm{Mo}, \mathrm{Ti})_{2} \mathrm{C}$. And the $(\mathrm{Ti}, \mathrm{Mo}) \mathrm{C} /(\mathrm{Mo}, \mathrm{Ti})_{2} \mathrm{C}$ interface is kept good coherency by the introduction of the ledges.

\section{Acknowledgments}

This work was supported by the Advanced Low Carbon Technology Research and Development Program (ALCA) of the Japan Science, Technology Agency (JST) and Japan Society for the Promotion of Science (JSPS) Grants-in-Aid for Scientific Research (KAKENHI) Grant Number 15K18229.

\section{References}

[1] Sakidja R, Myers J, Kim S, Perepezko JH. The effect of refractory metal substitution on the stability of $\mathrm{Mo}(\mathrm{ss})+\mathrm{T}_{2}$ two-phase field in the Mo-Si-B system. Int J Refract Met Hard Mater 2000;18:193-204.

[2] Choe H, Chen D, Schneibel JH, Ritchie RO. Ambient to high temperature fracture toughness and fatigue-crack propagation behavior in a $\mathrm{Mo}-12 \mathrm{Si}-8.5 \mathrm{~B}$ (at.\%) 
intermetallic. Intermetallics 2001;9:319-29.

[3] Schneibel JH, Kramer MJ, Ünal Ö, Wright RN. Processing and mechanical properties of a molybdenum silicide with the composition $\mathrm{Mo}-12 \mathrm{Si}-8.5 \mathrm{~B}$ (at.\%). Intermetallics 2001;9:25-31.

[4] Dimiduk DM and Perepezko JH. Mo-Si-B Alloys: Developing a revolutionary turbine-engine material. MRS Bulletin 2003;28:639-45.

[5] Schneibel JH. High temperature strength of $\mathrm{Mo}-\mathrm{Mo}_{3} \mathrm{Si}-\mathrm{Mo}_{5} \mathrm{SiB}_{2}$ molybdenum silicides. Intermetallics 2003;11:625-32.

[6] Alur AP, Chollacoop N, Kumar KS. High-temperature compression behavior of Mo-Si-B alloys. Acta Mater 2004;52:5571-87.

[7] Alur AP, Chollacoop N, Kumar KS. Creep effects on crack growth in a Mo-Si-B alloy. Acta Mater 2007;55:961-74.

[8] Yang Y, Chang YA, Tan L, Cao W. Multiphase equilibria in the metal-rich region of the Mo-Ti-Si-B system: thermodynamic prediction and experimental validation. Acta Mater 2005;53:1711-20.

[9] Krüger M, Schliephake D, Jain P, Kumar S, Schumacher G, Heilmaier M. Effects of $\mathrm{Zr}$ additions on the microstructure and the mechanical behavior of PM Mo-Si-B alloys. JOM 2013;65:301-6. 
[10] Yang Y, Bei H, Tiley J, George EP. Re effects on phase stability and mechanical properties of $\mathrm{Moss}_{5}+\mathrm{Mo}_{3} \mathrm{Si}+\mathrm{Mo}_{5} \mathrm{SiB}_{2}$ alloys. J Alloys Compd 2013;556:32-8.

[11] Majumdar S, Kumar A, Schliephake D, Christ H-J, Jiang X, Heilmaier M, Microstructural and micro-mechanical properties of Mo-Si-B alloyed with $\mathrm{Y}$ and La. Mater. Sci. Eng. A 2013;573:257-63.

[12] Hochmuth C, Schliephake D, Völkl R, Heilmaier M, Glatzel U. Influence of zirconium content on microstructure and creep properties of $\mathrm{Mo}-9 \mathrm{Si}-8 \mathrm{~B}$ alloys. Intermetallics 2014;48:3-9.

[13] Nakamura J, Kaneko T, Hara T, Yoshimi K, Maruyama K, Katsui H, et al. Site-occupation behavior and solid-solution hardening effect of rhenium in $\mathrm{Mo}_{5} \mathrm{SiB}_{2}$. Intermetallics 2014;53:85-91.

[14] Miyamoto S, Yoshimi K, Ha SH, Kaneko T, Nakamura J, Sato T, et al. Phase equilibria, microstructure, and high-temperature strength of TiC-added Mo-Si-B alloys. Metall Mater Trans A 2014;45:1112-23.

[15] Yoshimi K, Nakamura J, Kanekon D, Yamamoto S, Maruyama K, Katsui H, et al. High-temperature compressive properties of $\mathrm{TiC}-$ added $\mathrm{Mo}-\mathrm{Si}-\mathrm{B}$ alloys. JOM 2014;66:1930-8.

[16] Moriyama T, Yoshimi K, Yokoyama T, Masnou T, Zhao M, Nakamura J, Katsui H, 
Goto T. Intermetallics (to be submitted).

[17] Ryan NE, Soffa WA, Crawford RC. Orientation and habit plane relationships for carbide and nitride precipitates in molybdenum. Metallography 1968;1:195-220.

[18] Igarashi T. Strengthening and toughening of molybdenum by corbide particles. J. Jpn. Soc. Powder Powder Metall 2002;49:163-71.

[19] Morita K, Uehara M, Tsurekawa S, Nakashima H. Structures and impurity effect on symmetric tilt boundaries of molybdenum. J. Jpn. Inst. Metals 1997;61:251-60.

[20] Hoshika T, Hiraoka Y, Nagase M, Takada J. Hardness distribution of molybdenum alloys which performed carbonization treatment. J. Jpn. Soc. Powder Powder Metall 2002;49: 32-6.

[21] Kumar A, Eyre BL. An electron microscope study of $\mathrm{Mo}_{2} \mathrm{C}$ precipitates in molybdenum-I. crystallographic relationships. Acta Metall 1978;26:569-77.

[22] Epicier T, Dubois J, Esnouf C, Fantozzi G. Neutron powder diffraction studies of transition metal hemicarbides $\mathrm{Mo}_{2} \mathrm{C}_{1-\mathrm{x}}-\mathrm{II}$. in situ high temperature study on $\mathrm{W}_{2} \mathrm{C}_{1-\mathrm{x}}$ and $\mathrm{Mo}_{2} \mathrm{C}_{1-\mathrm{x}}$. Acta Metall 1988;36:1903-21.

[23] Kikuchi M, Nagakura S, Oketani S. Crystal structures of transition metal carbides. Tetsu to Hagane 1971;57:1009-53. 
[24] Aaronson HI, Spanos G, Masamura RA, Vardiman RG, Moon DW, Menon ESK, et al. Sympathetic nucleation: an overview. Mater. Sci. Eng. B 1995;32:107-23.

[25] Oku N, Asakura K, Inoue J, Koseki T. In-situ observation of ferrite plate formation in low carbon steel during continuous cooling process. Tetsu to Hagane 2008;94:363-8. 


\section{Figure Captions}

Figure 1. XRD pattern of the MoSiBTic alloy.

Figure 2. SEM-BSE micrographs of MoSiBTiC alloy. (a) An overview of microstructure.

(b) Part of a fine $\mathrm{Mo}_{\mathrm{ss}}+(\mathrm{Ti}, \mathrm{Mo}) \mathrm{C}+(\mathrm{Mo}, \mathrm{Ti})_{2} \mathrm{C}$ four phase area. (c) $\mathrm{Mo}_{\mathrm{ss}} /(\mathrm{Mo}, \mathrm{Ti})_{2} \mathrm{C}$ interface.

Figure 3. STEM bright field images and EDS maps of $\mathrm{Mo}_{\mathrm{ss}} /(\mathrm{Mo}, \mathrm{Ti})_{2} \mathrm{C}$ interface. (a) Lower-magnification STEM image. (b) Higher-magnification STEM image. (c) Ti-Ka map. (d) Mo-L $\alpha$ map.

Figure 4. (a) HAADF-STEM image of $\mathrm{Mo}_{\mathrm{ss}} /(\mathrm{Ti}, \mathrm{Mo}) \mathrm{C} /(\mathrm{Mo}, \mathrm{Ti})_{2} \mathrm{C}$ interface. (b) SAED pattern of $\mathrm{Mo}_{\mathrm{ss}} /(\mathrm{Ti}, \mathrm{Mo}) \mathrm{C} /(\mathrm{Mo}, \mathrm{Ti})_{2} \mathrm{C}$ interface. (c) Schematic illustration of $\mathrm{Mo}_{\mathrm{ss}} /(\mathrm{Ti}, \mathrm{Mo}) \mathrm{C} /(\mathrm{Mo}, \mathrm{Ti})_{2} \mathrm{C}$ interface. (d) HAADF-STEM image of (Ti,Mo)C/(Mo,Ti) ${ }_{2} \mathrm{C}$ interface. (e) Atomic model of Mo atom arrangement at tip of ledge.

Figure 5. (a) and (b) HAADF-STEM images around the tip of a blade-shaped $\mathrm{Mo}_{\mathrm{ss}} /(\mathrm{Mo}, \mathrm{Ti})_{2} \mathrm{C}$ interface. (c), (d), (e), and (f) Schematic illustrations of the formation mechanism of the blade-shaped interface. 


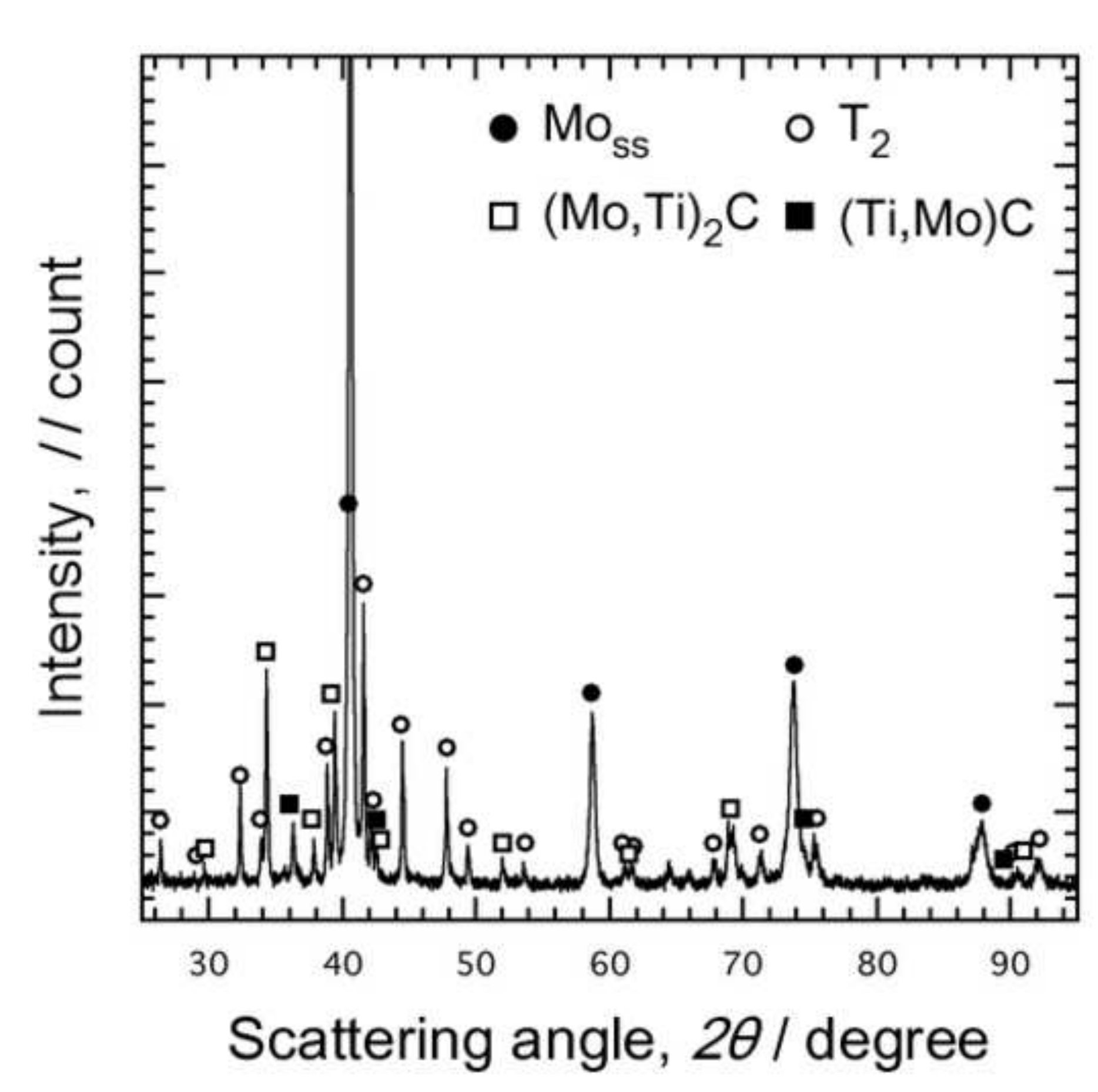

Figure

\section{Figure 1 Nakamura et al.}



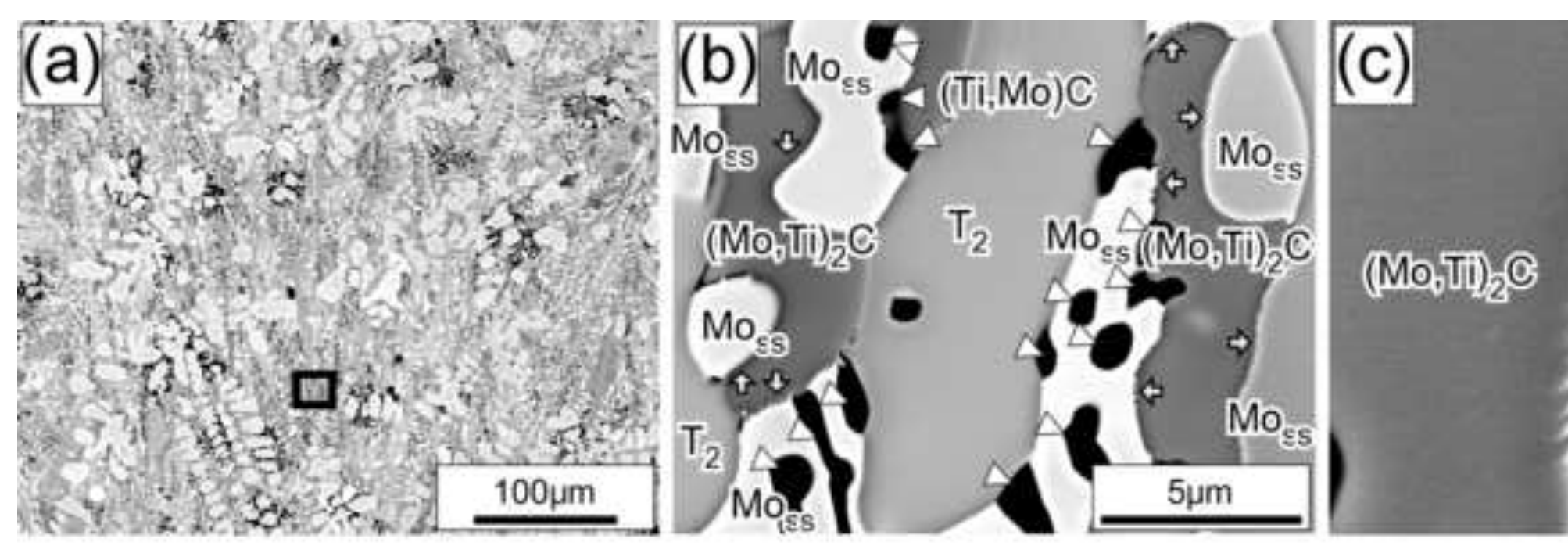

$\mathrm{Mo}_{\text {ss }}$

Figure 2 Nakamura et al. 

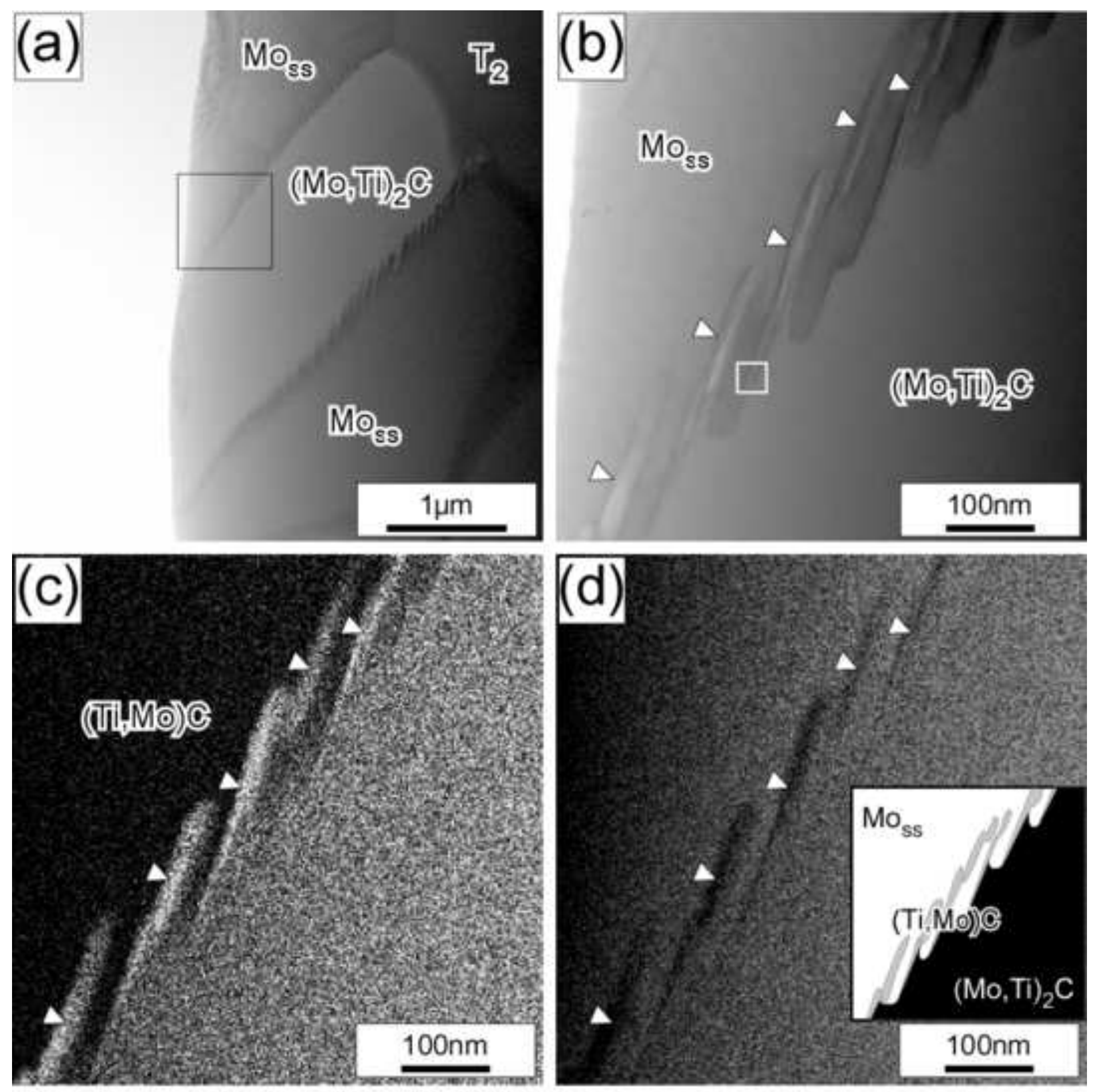

\section{Figure 3 Nakamura et al.}



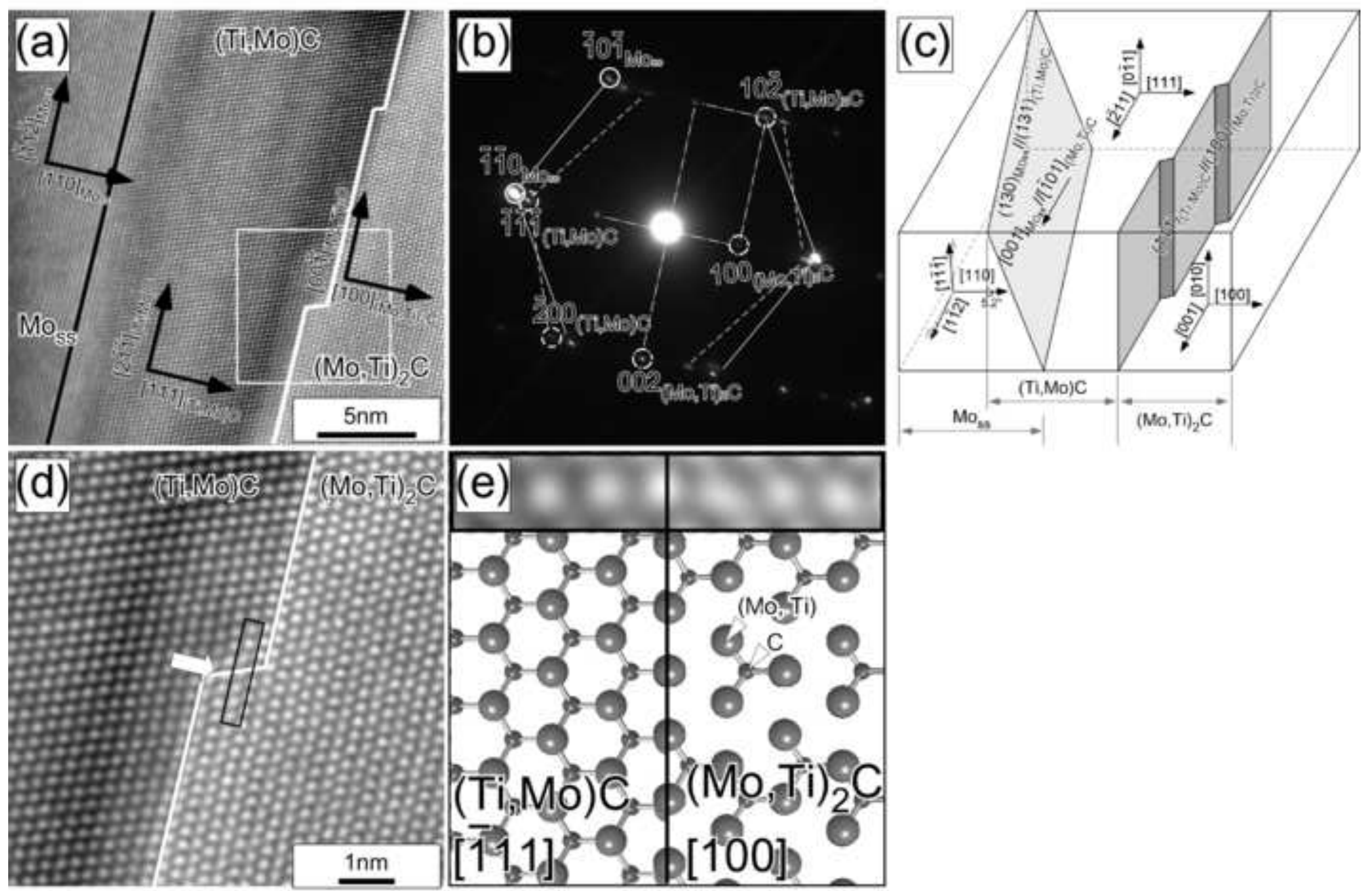

Figure 4 Nakamura et al. 

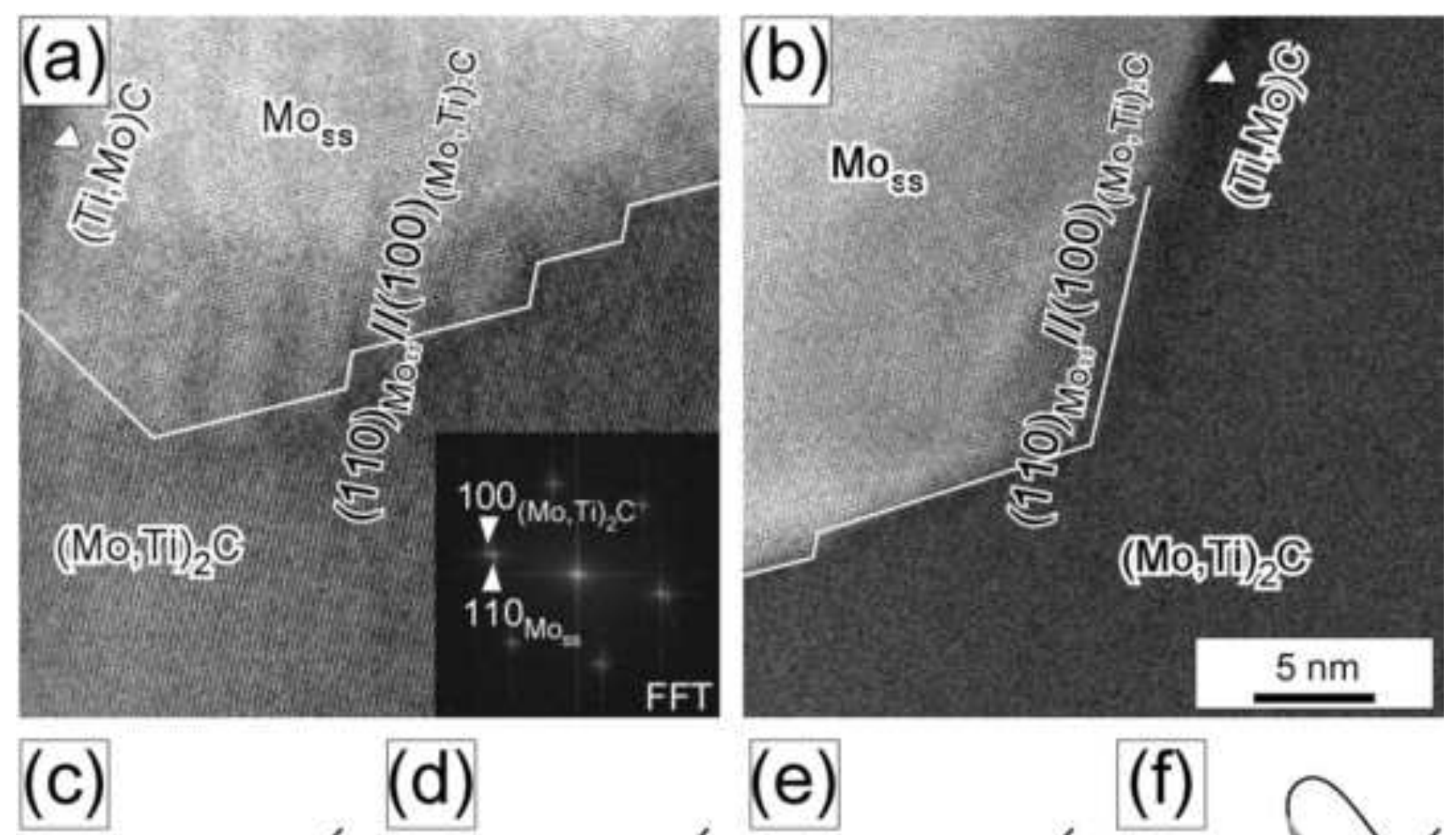

(d)

(e)

(f)

$(\mathrm{Mo}, \mathrm{Ti})_{2} \mathrm{C}$

$\left(\mathrm{Mo}, \mathrm{Ti}_{2} \mathrm{C}\right.$

$(\mathrm{Mo}, \mathrm{Ti})_{2} \mathrm{C}$

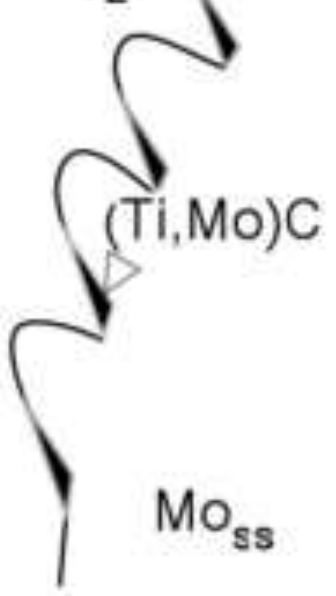

$\mathrm{Mo}_{\text {ss }}$

\section{Figure 5 Nakamura et al.}




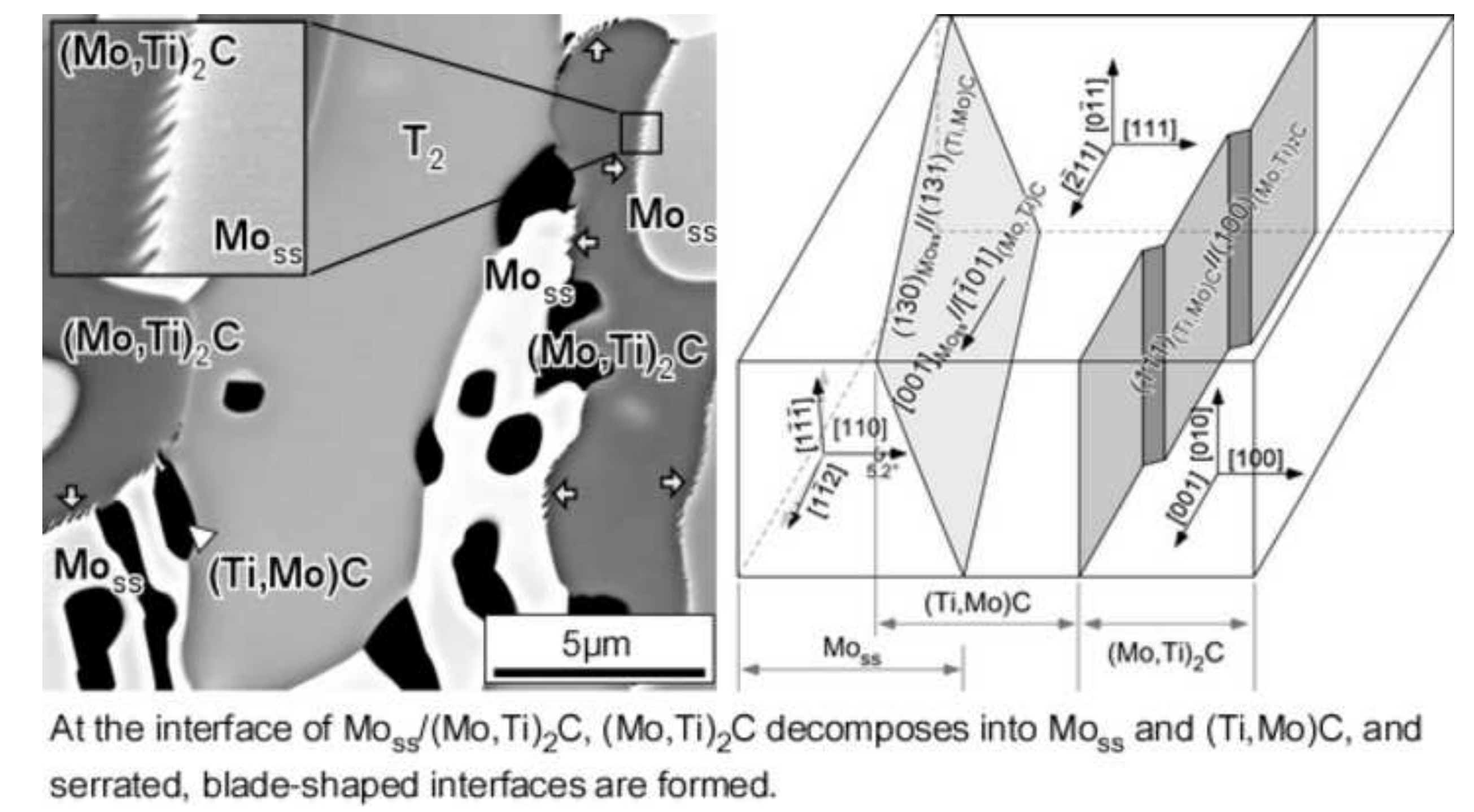

At the interface of $\mathrm{Mo}_{\mathrm{ss}} \mathrm{J}(\mathrm{Mo}, \mathrm{Ti})_{2} \mathrm{C},(\mathrm{Mo}, \mathrm{Ti})_{2} \mathrm{C}$ decomposes into $\mathrm{Mo}_{\mathrm{ss}}$ and $(\mathrm{Ti}, \mathrm{Mo}) \mathrm{C}$, and

serrated, blade-shaped interfaces are formed.
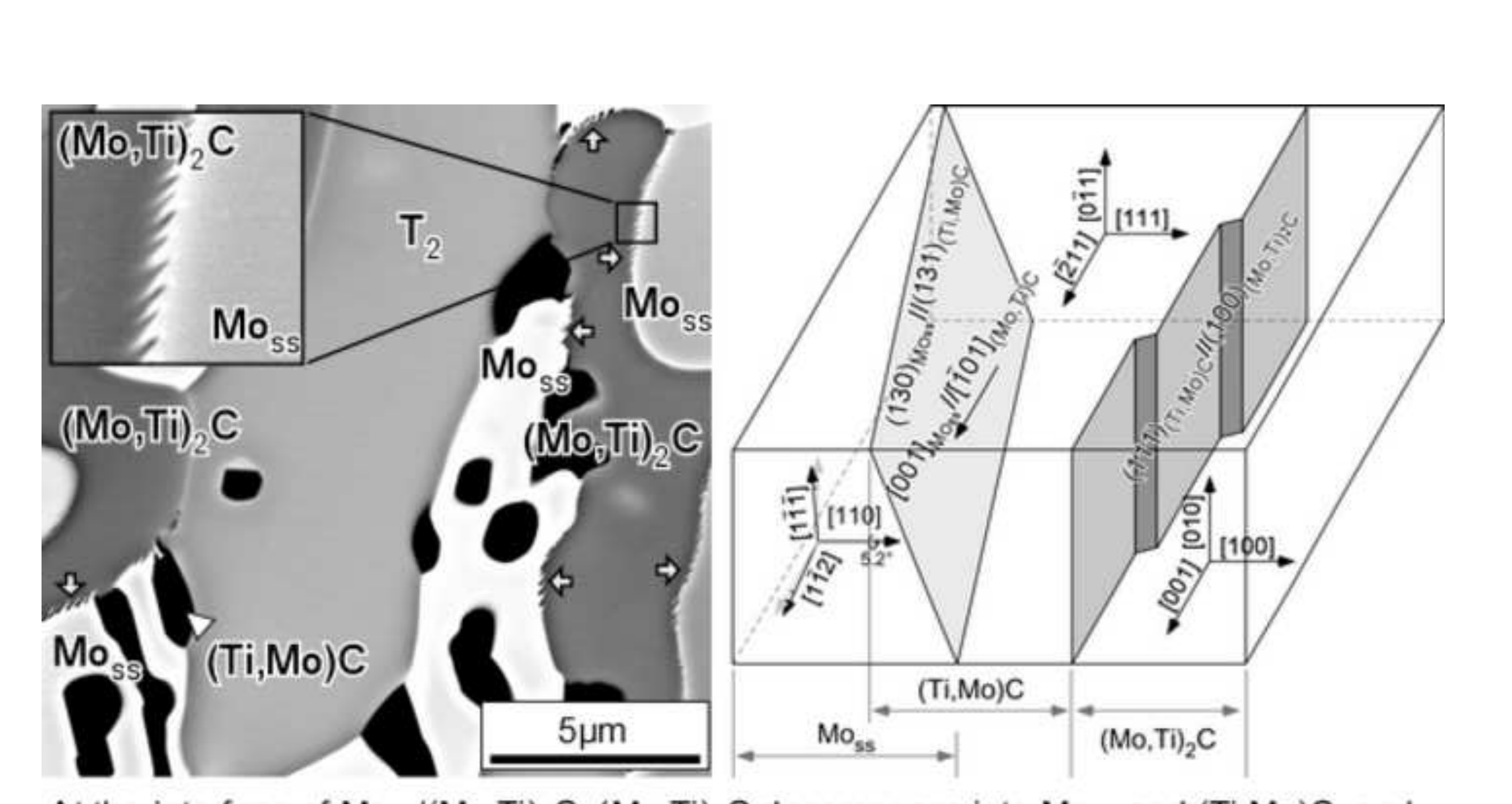

.

. 